\title{
«Тарас Бульба» Н. В. Гоголя и «Хаджи-Мурат» Л. Н. Толстого (аспект историософии, исторической поэтики и интертекстуальности)
}

\author{
СЕРГЕЙ ШУЛЬЦ \\ 3-я линия, д. 5, кв. 28, RU-344019 Ростов-на-Дону \\ E-mail: s_shulz@mail.ru
}

(Received: 19 March 2017; accepted: 4 July 2017)

\begin{abstract}
This paper is based on three major premises derived from philosophy of history, historical poetics, and theory of intertextuality, which are seen as interconnected. Taras Bulba and Khadzhi Murat inherit different forms of epic writing from archaic ones (e.g. epic poems) to heroic ones (e.g. sagas, bylinas, chivalric romance, etc.). Some variations and distant derivatives of these multiple forms (e.g. tales about bogatyrs, Orlando Furioso by Ariosto, Alonso Quijano by Cervantes, ballad, historical novella, etc.) are related to some extent to the given texts by Gogol and L. Tolstoy.
\end{abstract}

Keywords: Russian literature, Gogol, L. Tolstoy, philosophy of history, historical poetics, theory of intertextuality

Данная статья опирается на три основные линии изложения материала историософскую, поэтологическую (в историческом измерении), интертекстуальную. Эти линии пересекаются. С одной стороны, автор пытается рассматривать предмет в широком философско-историческом контексте, с постоянными экскурсами в самую историю и ее движущийся смысл, как он понимался близкими Гоголю и Толстому мыслителями и писателями. С другой стороны, мы поднимаем проблемы исторической поэтики в качестве прослеживания объективной преемственности и взаимоперехода различных жанров художественной мысли.

Мы будем опираться на две версии исторической поэтики: М. М. Бахтина (фрагментарность, сопоставления различных литературных феноменов без учета возможных опосредующих звеньев) и Е. М. Мелетинского (выстраивание неких общих линий развития жанров - в случае данной статьи выясняется место повестей Гоголя и Толстого преимущественно в единой линии развития архаического и героического эпоса). Проводимые далее параллели имеют объективный характер, то есть они по большому счету не зависят от субъективных намерений творцов.

Но ведь жанры также укоренены в истории, пронизаны ее живым самодвижением, они несут экзистенциально-историософский смысл в самом своем гештальте. Интертекстуальность, о собственном специфическом толковании которой мы скажем чуть ниже, прямо коррелирует с двумя названными выше линиями. 
«Тарас Бульба» и «Хаджи-Мурат» наследуют прежде всего различным формам эпоса, от архаического (эпопея) до героического (в том числе сага, былина, рыцарский роман и др.). Вариации и отдаленные превращенные дериваты этих разнообразных форм (богатырская сказка, «Неистовый Роланд» Ариосто, «Дон Кихот» Сервантеса, баллада, историческая повесть и др.) также имеют то или иное значение для рассматриваемых текстов Гоголя и Толстого.

Гоголь ввел особое понятие «малых родов эпопеи», к которым относил кое-что из названного выше, что мы еще подробно рассмотрим. Моменты «возвышенного», «поэтического» в текстах Гоголя и Толстого заставляют говорить и о связи с лирикой (Радищев, поэт XX века П. Целан).

Наш анализ не мог не включить в себя значительных элементов интертекстуальности, по-бахтински неортодоксально понятой нами в виде глубоко историального и исторического самодвижения, перекрещивания, взаимоналожения и взаимопревращения различных по времени происхождения духовных смыслов, символов, образов, мотивов, сюжетов, других элементов произведения - т. е. вообще самых разнообразных элементов «игры искусства» (Г. Г. Гадамер), проецирующихся прежде всего на экран жанровой сферы.

Ю. Кристева возводила теорию интертекстуальности к Бахтину, но она не взяла в собственную версию этой методологии прежде всего бахтинский духовный историзм. Так же в основном поступают не только ее последователи, но и те, кто с нею полемизирует. Мы пытаемся, насколько возможно, восполнить это упущение.

Бахтин понимал текст как своеобразную монаду, стягивающую к себе все остальные тексты данной смысловой сферы. В такой трактовке есть даже нечто и от гегелевской идеи Абсолютного духа с ее широчайшим духовным историзмом, с ее, по верному замечанию Хайдеггера, попыткой осмыслить Абсолют во всей его полноте.

Вместе с тем, например, в самих гегелевских позднейших «Лекциях по философии истории» такого историзма, как ни странно, почти нет. Зато он мощно задан, в частности, в «Феноменологии духа», менее сильно - в «Лекциях по истории философии», «Энциклопедии философских наук»... Однако бахтинский духовный историзм, в отличие от гегелевского, полностью нелинеен, внесистемен, антииерархичен. Вот эти последние качества в бахтинском наследии для нас особенно привлекательны. Тем самым Абсолют, воплощающий себя, в частности, в истории, искусстве, живых или лишь временно помертвевших духовных смыслах, понимается нами нелинейно и антииерархически.

Начнем изложение с собственно историософской линии, постоянно переходя затем на тесно сплетенные с нею линию собственно поэтологическую (историческая поэтика) и интертекстуальную.

В своей «Истории учения о цвете» Гете заметил: «В наши дни уже не осталось сомнения в том, что всемирную историю надо время от времени переписывать» (цит. по МейнекЕ 2004: 396). Осуждая авторов XVIII века, 
«редко», по его мнению, терпеливых «по отношению к медленному становлению», видя в них отсутствие «благоговения перед высокими невыполнимыми требованиями», отсутствие «чувства серьезности» относительно «неизведанных глубин», Гете надеялся, что XIX век многое поменяет - «если только он... не затеряется в противоположном» (цит. по МЕйНЕКЕ 2004: 397).

Необходимо прежде всего маркировать в гетевском высказывании фразу «время от времени», что свидетельствует о признании необходимости постоянных новых интерпретаций цепи исторических событий. Данная оценка явилась, по мнению Ф. Мейнеке, «одним из самых достопримечательных свидетельств осознания нового понимания истории» (МЕйНЕКЕ 2004: 396), которое можно назвать ответственно релятивным историзмом, т. е. ответственно принимающим свою относительность.

Примечательная черта в этом новом понимании - проблематизация самого понятия «исторического», позволившая, в частности, Хайдеггеру в XX веке разграничить «историографию» (фиксацию исключительно прошлого) и подлинную «историю» (устремленность в будущее, охватывающую всю целостность потока времени) (БРосовА 2006: 157).

Гоголь и Толстой, писатели XIX века, обращаясь в своих произведениях к истории (в том числе к «истории современности»), постоянно ее «переписывали». Делая это и в самом буквальном отношении - достаточно упомянуть про две разнонаправленные редакции «Тараса Бульбы» или про многочисленные противоречащие один другому варианты «Хаджи-Мурата». Это свидетельствует, с одной стороны, о динамике авторских замыслов, поиске аутентичного восприятия прошлого и настоящего. Однако «переписывание» имело значение и более сложное, сущностное.

В последнем случае дело идет именно о заданном Гете «чувстве серьезности», хотя и осложняемом-дополняемом у рассматриваемых авторов XIX века иронией и комизмом, об их погружении в «неизведанные глубины», являющемся глубоко полемическим, о самом неподдельном пристальном интересе их к «медленному становлению» изображаемых явлений, осознаваемому через соотнесение имманентного взгляда на прошлое (длящееся прошлое) со взглядом с точки зрения современности, а также о признании связи истории как рефлексии с «идеологией» в широком значении (идея, тематизированная в XX веке Г. Лукачем, но перекликающаяся с моментом релятивизма в высказывании Гете).

Правда, в самом этом скрупулезно изображаемом «медленном становлении» цепи времени Гоголь и Толстой увидят разное. Первый - взлет «гордой» птицы гоголь (Гоголь 2: 413); таков финал второй редакции «Тараса Бульбы» (название птицы вводится Гоголем в качестве маркера собственной «птичьей» автомифологии), соотносящийся со взлетом птицы-тройки из первого тома «Мертвых душ», а это взлет по ту сторону земного - эсхатологический.

Гоголь в «Тарасе Бульбе» будто бы не упоминает прямо также и о Киевской Руси, однако он, безусловно, имеет в виду этот общий для Великороссии и Малороссии исток. В связи с темой Киевской Руси любопытно было 
бы отметить некоторые переклички между не вполне эксплицированными взглядами на этот период Гоголя и позицией философа В. С. Соловьева, выраженной им в политико-историософской статье «Владимир Святой и христианское государство».

Соловьев, в частности, видит в князе Владимире приверженца антиэтатизма и открытости христианскому Западу. Искомый идеал Соловьева близок, по собственному мнению философа, князю Владимиру - это теократия (СолОвьев 1999).

Запорожская Сечь у Гоголя в самом деле основана на принципе антиэтатизма, даже полуанархизма, хотя писатель подразумевает, что данный принцип все же сверху поддерживается абсолютистской властью царя; тут отчасти находится место и для идеала теократии (через культ религии у запорожцев), более явно выраженного в «Выбранных местах из переписки с друзьями». Что касается католичества, то отношение к нему Гоголя не было негативным, как и у В. С. Соловьева, мечтавшего повернуть Россию в сторону западного христианства.

Хотя в «Тарасе Бульбе» антикатолические настроения выражены довольно сильно, но, видимо, только потому, что католицизм ассоциируется в повести с нарушителями самобытности Малороссии и России в целом поляками. И. А. Виноградов высказал предположение, что Гоголь хотел во второй редакции «Тараса Бульбы» развеять мнение тех своих современников, кто воспринимал писателя как слишком симпатизирующего католичеству (Виноградов 1997). Укреплению мнения И. А. Виноградова не способствует то, что антикатолические настроения достаточно сильны и в первой редакции повести.

Толстой же опознает в «медленном становлении» - за внутренними и внешними изменениями, непростыми, хотя и нравственно отчетливыми мотивировками поступков Хаджи-Мурата - победу био-космо-природной жизни, «общей жизни». Но она ведь может существовать у Толстого только через «анархического» индивида (каковым и является Хаджи-Мурат), побеждающего даже в смерти - ср. полуанархизм гоголевской Сечи. Здесь трагизм и античного типа (власть над индивидом обстоятельств, «фатума»), и шекспировского (подробно расписана вся «внутренняя» индивидуальность протагониста, по-предмодернистски данная через «экран» его сознания и также служащая причиной трагизма).

Однако Гоголь и Толстой при всем их интересе к становлению, созреванию исторического постоянно отмечают также перебивы, срывы, зигзаги, выпадающие из телеологии шлегелевско-гегелевского образца падения и «взлеты», оказывающиеся у двух авторов незавершимыми в принципе (идея самосовершенствования), прерываемыми лишь смертью, да и то относительно.

Эти перебивы вечного становления, словно бы и не приводящего к итоговому результату (не могущего закончиться), все остающегося процессом, заставляют двух авторов поспорить о «единстве» хода времени, поразмышлять о роли в нем «чуда». 
У Толстого, в отличие от Гоголя, чудесного, безусловно, поменьше, но особая роль отводится различным мелким обстоятельствам и деталям, заменяющим «чудесное», «сверхъестественное» и объективно складывающимся в целое, в сцепление «воль». Не во внимании ли названных писателей к этим срывам и перебивам - оправдание обмолвки Гете о том, что XIX век может вдаться и в крайность противоположности веку Просвещения?

Известно, что вплоть до XVIII века история как рефлексия рассматривалась в качестве своеобразного рода словесности. Вероятно, именно данный факт послужил одним из толчков для гетевского императива переинтерпретаций истории и для самой проблематизации им понятия исторического.

Гоголь и Толстой, несомненно, помнят о корреляции двух названных видов дискурса (словесность, с одной стороны, - и собственно история как рефлексия, с другой), поэтому в какие-то моменты возникает вопрос: история перетекает в литературу или наоборот (вспомним все малороссийские исторические тексты Гоголя, его незаконченную драму из английской истории «Альфред»; укажем на «Войну и мир», а также толстовские замыслы романа из петровской эпохи, романа о декабристах).

В номинальном значении «Тарас Бульба» и «Хаджи-Мурат» - повести, действительно, «исторические». И для Гоголя (учитывая вторую редакцию повести - 1842 г.), и для Толстого это - одно из последних обращений к истории в качестве прошлого, длящегося, впрочем, прошлого. Но подобная номинальность не делает их произведения «историографическими» в хайдеггеровском значении, т. к. в них сохраняется восприятие целостности потока времени. Номинация «историческая повесть» вовсе не исчерпывает жанровое содержание и жанровую форму двух рассматриваемых повестей.

Однако сопоставление «Хаджи-Мурата» с историческим романом (исторической повестью) Пушкина «Капитанская дочка» (Шкловский 1959: 132, Бойко 1983: 490) в значительной степени заслуживает внимания. Другое дело, что роман Пушкина выступает претекстом по отношению к прежде всего «Тарасу Бульбе» - и уже тем самым к «Хаджи-Мурату». Изображение Пушкиным войны, образ бунтаря-одиночки (Пугачев), ирония и вместе с тем воодушевление нарратора - все это напоминает о коллизиях «Тараса Бульбы» и уже через него - о «Хаджи-Мурате». И гоголевская, и толстовская повесть в жанровом плане романизированы.

С учетом проблематизации понятия исторического у названных авторов нельзя не увидеть черты полемичности сравнительно с «чистой» исторической повестью / романом, а также элементы ряда других жанровых образований. Не надо закрывать глаза на пафос будущего в «Тарасе Бульбе»; он есть, хотя и с иными акцентами, в «Хаджи-Мурате»; повесть Толстого приобретает в конечном счете антиисторический пафос, зафиксированный Б. М. Эйхенбаумом еще применительно к «Войне и миру» (ЭйхенБАум 1931).

В связи с продуктивной проблематизацией исторического у Гоголя и Толстого отметим также их полурефлективное-полуинтуитивное возвращение к тому, что Гегель назвал «героическим состоянием мира», при котором 
высшие ценности существования - доблесть, честь и т. д. - не отчуждены от человека в виде абстрактных категорий «власти», «государства» и т. д., а реализуются непосредственно через индивида (ГЕГЕЛь 2001: 238-250). По отношению к Толстому подобную мысль высказал А. А. Казаков на материале «Войны и мира» (КАзАКов 2012: 344-346; ср. также Сухих 1987: 179).

«Героическое» в случае названных повестей означает реанимацию архаики, которая у Толстого предстает не столько в виде прошлого, сколько в виде цели - искомого будущего без «государства», «власти», разделения на властителей и подчиненных, вражды народов и т. д.

Создаваемые Гоголем и Толстым художественно-исторические феномены обращены не только к собственно «эстетическому» взгляду, но к восприятию в широком значении экзистенциально-жизненному, только частью которого выступает социально-политический аспект.

Такое экзистенциально-жизненное восприятие свойственно «органической критике» А. Григорьева, течению «философия жизни», особенно в дильтеевском его варианте, тем же А. Григорьевым предвосхищенном. В. Дильтей придал категории жизни значение уникальности, движения, творчества - значение историзма. Но термин «философия жизни» встречается уже у Ф. Шлегеля, так что подобная категория в любом случае может быть распространена и на наследующего романтикам Гоголя, а не только на Толстого.

В. Дильтей писал о том, что «значение» выступает одной из категорий самой исторической жизни, т. е. что оно соприродно ей, изменяется вместе с нею, что поэт «схватывает значительность жизни» (ДильтЕй 2001: 432-433) (понятой исторически). Это корреспондирует пафосу ответственной релятивности Гете и во многом близко рассматриваемым в статье двум писателям, являющим в названных повестях свой дар исторических «поэтов».

Постоянные соотнесения двумя авторами изображаемого ушедшего «героического» мира с настоящим, с одной стороны, а также с будущим, с другой стороны, нарочитый акцент именно на ответственно релятивном «переписывании» истории (хотя, вероятно, самый релятивизм не вполне осознавался - но осознавалась ответственность) привносит в произведения двух авторов, если рассматривать их в аспекте исторической поэтики и интертекстуальности, элементы различных жанровых образований - в частности, древнего $^{1}$ и классического (средневекового) героического эпоса, ${ }^{2}$ а также

${ }^{1}$ О связи «Тараса Бульбы» с «Илиадой» писал еще В. Г. Белинский, однако позднее он же почему-то возмутился предложенным К. С. Аксаковым соотнесением «Мертвых душ» с гомеровским эпосом. Из работ на тему связи «Тараса Бульбы» с «Илиадой» см., в частности, ProfFER 1967: 166-182, ГРИФФИТс-РАБИнович 2005: 77-98. Когда В. В. Федоров описывал жанровый конфликт «Тараса Бульбы» как конфликт эпопеи и романа (см. ФЕдоРОв 1985: 162), он имел в виду только архаическую форму эпопеи, но не средневековую, а под романом понимал нечто скорее реалистическое. Подобный подход слишком узок. К тому же и в архаической эпопее возможны коллизии, близкие повести Гоголя в ее романном измерении.

${ }^{2}$ О различии архаического и классического героического эпоса см. МЕлЕтинский 2001: $62-74$. 
близкого последнему рыцарского эпоса, рыцарского романа, ${ }^{3}$ явившегося, в частности, субстратом жанра «Дон Кихота», о рецепции которого Гоголем и Толстым в их повестях еще будет говориться.

Кроме того, в «Тарасе Бульбе» и «Хаджи-Мурате» отразились восходящие в плане исторической поэтики также к средневековому, по преимуществу, героическому эпосу (МЕЛЕтинский 1994) элементы саги, исторической песни, баллады (Пумпянский 2000), ${ }^{4}$ а также перерабатывающей легенды и предания сказки - в данном случае, богатырской сказки. ${ }^{5}$

Все названные архаические жанровые модели, трансформируясь, несут с собою в произведения Гоголя и Толстого в качестве «застывшего содержания» (Бахтин) и элементы (подчеркнем: только элементы) своих мировоззрений. Отсюда столь строгое деление на «своих» и «чужих», принимаемое Гоголем с оправдательной ссылкой на нравы «свирепого» века, но уже подвергаемое сомнению Толстым.

Трансформация приводит к особому жанровому синтезу или даже менее строгой в отношении целостности общей жанровой модели диффузии. А условный, не вполне последовательный, «презентизм» (Хабермас) гоголевской и толстовской повестей, т. е. акцентирование точки зрения настоящего, не противореча историзму, но являясь в данном случае его превращенной формой, придает текстам элементы в широком значении романтического романа / романтической повести. Хотя Толстой в целом чужд романтизму как школе, но его Хаджи-Мурат, как мало кто из его персонажей, напоминает романтического героя. Есть в толстовской повести и романтический «местный колорит». Под повестью как специфически русским жанром в данном случае понимается малый вид романа, что было сформулировано В. Г. Белинским.

Предлагая отказаться от презентизма в целом, А. В. Михайлов отмечает его будто бы неисторизм (МихАйлов А. В. 2006), однако это не вполне так: нужно увидеть определенную вписанность презентизма в общий контекст, его связь с ходом времени. «Презентизм» в данном случае нужно понимать именно в качестве разновидности историзма.

Обе повести устремлены в будущее, исполнены «утопии о человеке» (С. Г. Бочаров), каким ему должно стать, пока история / эсхатология не завершила мировое сущее (Гоголь), пока человек не преобразился и не вернулся в космо-гео-природное - оно же не только прошлое, но и будущее (Толстой).

${ }^{3}$ О близости средневекового героического эпоса и рыцарского романа см. МихАйлов А. Д. 1976, МиХАйЛОв А. Д. 1995, МЕЛЕТинСкий 1994.

${ }^{4}$ Исследователь афористично называет балладу, элементы которой он находит в «Тарасе Бульбе», «внутренним переживанием истории». Такими «переживателями» истории являются и нарратор «Тараса Бульбы», и его герои.

5 Элементы сказки (не уточнив, что богатырской) обнаружил в «Тарасе Бульбе» В. Ш. Кривонос (см. Кривонос 2006: 36-38, 45-46). В том факте, что Тарас погибает из-за желания подобрать упавшую люльку, исследователь также видит элементы сказки (КРивонос 2006: 129 ), но он не замечает определенной иронии нарратора по поводу такого (хотя и в зоне Тараса оправданного) внимания протагониста к люльке в подобной ситуации. 
«Тарас Бульба» во второй редакции имеет тенденцию ритуального восхваления России, тем самым не только московского царя, о чем писал Л. В. Пумпянский, но и царя петербургского, династии Романовых в целом, к которой Гоголь, в отличие от Толстого, был весьма привязан. Хотя в «Тарасе Бульбе» (особенно в первой его редакции) постоянно изображаются, всегда с юмором и карнавальностью, всевозможные вольности, свободы и полуанархия социально-политического устройства Сечи.

О ритуальной в своих архаических истоках хвале как цели «Тараса Бульбы» говорят часто упоминаемые Гоголем в его повести ее претексты - исторические песни, сказания певцов-бандуристов. Это - «слава», которую поют народные сказители уже своим современникам, а также предкам запорожцев и будут петь их потомкам.

После осады Дубна сыновья Тараса задумываются о значении благословения матери, приславшей им кипарисовые святые образа: «Что-то пророчит им и говорит это благословенье? Благословенье ли на победу над врагом и потом веселый возврат в отчизну с добычей и славой, на вечные песни бандуристам, или же...» (Гоголь 2: 341). В «или же...» вкладывается мотив будущего отступничества Андрия, в первой части антитезы задается последующее восславление Остапа.

Следует, однако, зафиксировать признание нарратором и героями повести возможного негативного действия благословения - не потому ли в данном случае, что оно напоминает о слишком мирной, домашней жизни, о матери, отношение к которой у отца самое строгое, а не о самом отце?

Любопытно, что нарратор так или иначе противопоставляет песни-восславления бандуристов (на свою близость к идее и форме этих восславлений он постоянно намекает) летописям, скорее всего, в силу антагонизма «живого» и «книжного» слова; о данном антагонизме Гоголь прямо говорил в первом томе «Мертвых душ» (завершавшемся параллельно со второй редакцией «Тараса Бульбы»): «Нечего описывать всех битв, где показали себя казаки, ни всего постепенного хода кампании [контрастно замечанию Гете, момент «постепенности» в данном случае опускается, но не в качестве ненужного, а в качестве будто бы уже известного - С. Ш.]: все это внесено в летописные страницы. Известно, какова в Русской земле война, поднятая за веру. Нет силы сильнее веры. Непреоборима и грозна она, как нерукотворная скала среди бурного, вечно изменчивого моря〉 (Гоголь 2: 408).

Фраза о «нерукотворной скале» заставляет вспомнить о «нерукотворном» памятнике из пушкинской оды, о «Медном всаднике»- и пушкинском, и фальконетовском, имеющем в основании «Гром-камень», «скалу». Мотивы пушкинской оды «Памятник» Гоголь обыграет в том числе в «Выбранных местах из переписки с друзьями» (Шульц 2007), но и во второй редакции «Тараса Бульбы» рецепция данной оды заметна, как и жанра оды в принципе. С нерукотворной скалой сравнивается вера, «истинная» вера, вдохновляющая запорожцев - и Гоголя как их «восславителя» и «наследника». Кроме того, значение слова «скала» по-древнегречески такое же, что и у слова 
«камень», под которым в Новом Завете понимается и Христос, и св. Петр, и Церковь. Эпитет «нерукотворный» встречается в Новом завете, откуда он, вместе с образом «камня» / «скалы» / «памятника» скорее всего, и перешел к Пушкину; ср. в предсмертном стихотворении А. Н. Радищева «Осмнадцатое столетие»:

Мрачные тени созади, впереди их солнце;

Блеск лучезарный его твердой скалой отражен.

(РАдИЩЕВ 1938: 127)

Радищев воссоздал здесь образ фальконетовского монумента, воздвигнутого Петру Екатериной. Эта «твердая скала»- в данном случае скала могущества России, на которое хочет надеяться перед своей кончиной Радищев, чисто риторически или нет. Кроме того, мотив «скалы» обращает к образам Церкви и небесного покровителя императора Петра (как затем у Пушкина и Гоголя).

Когда Тарас скорбел о плененном поляками старшем сыне, «напрасно бородатые, седые бандуристы, проходя по два и по три, расславляли его казацкие подвиги - сурово и равнодушно глядел он на все» (Гоголь 2: 392). Тут, с одной стороны, налицо невнимание опечаленного пленом сына Тараса к песням и хвале, с другой - характерно, что «слава» поется непосредственно живущему.

Это - «слава», о которой в связи с языческим Бояном, символом древнего сказителя-пророка, говорится в зачине «Слова о полку Игореве»:

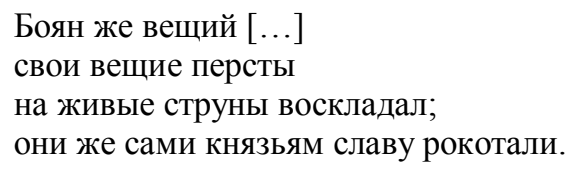

В языческие времена, вспоминаемые нарратором / автором «Слова о полку Игореве», «славу» «рокотали» сами «живые струны», что свидетельствует о медиуматическом творчестве поэта-пророка, о разделяемой автором «Слова» архаической идее действия через искусство-теургию реальных мистических сил («живые струны»), являющихся его основой. Можно увидеть в «живых струнах» и некое подобие Музы, также «живой»; все это именно так могло быть понято и принято самим Гоголем как автором «Тараса Бульбы» и «Мертвых душ». ${ }^{6}$ Вместе с тем Гоголь, безусловно, пытался и осовременить это «восславление». Отсюда наложение пафоса древности на пафос прямой

\footnotetext{
${ }^{6}$ Нередкие сопоставления «Тараса Бульбы» со «Словом о полку Игореве» обычно обходят этот жанрово-конститутивный аспект восславления, затрагивая только близость описания батальных сцен или описаний природы. О связи «Тараса Бульбы» со «Словом о полку Игореве» см. ПриймА 1954, ДушЕчкинА 1983, Гуминский 1985: 258 (здесь указано также значение для повести народных дум и песен), ТАМАРЧЕНКО 2001.
} 
презентистской дидактики во второй редакции «Тараса Бульбы». Подобное отчасти справедливо и относительно гоголевских попыток продолжения первого тома поэмы.

С уклоном в осовременивание «славы» Гоголем связаны моменты разрушения им всей линии классического героического эпоса, разрушения, которое Бахтин увидел еще в «Слове о полку Игореве». Исследователь наряду с элементами хвалы отметил в «Слове» элементы «посрамления» и «плача», поскольку оно, подобно «Песни о Роланде», рассказывает не о победе, а о поражении (БАХтин 1996: 39).

Внешнее поражение терпит у Гоголя и Тарасов род, но не его дело, поэтому названные Бахтиным элементы у Гоголя менее выражены. Интересно отметить в этой связи дальнейшее разрушение канонов эпоса у Толстого, где посрамление нарратора/автора направлено столько же против Шамиля, сколько против своих же: показательно в этой связи, например, фиксируемое в «Хаджи-Мурате» превращение Бутлера из друга протагониста в того, кто оправдывает усекновение его головы. Но ведь данное усекновение может напомнить и об участи Иоанна Крестителя; благодаря этой ассоциации фигура Хаджи-Мурата объективно вводится автором в христианский контекст.

«Слово о полку Игореве» в качестве средневековой вариации героического эпоса ведет к самому началу эпоса - архаике. Для таковой, в частности, характерна отмеченная Бахтиным дистанция между описываемым событием прошлого («абсолютного» прошлого) и временем нарратора, это прошлое можно только апологетизировать, но нет «фамильярного» контакта между изображаемым и изображающим.

У Гоголя подчеркивание такой дистанции двусмысленно: оно призвано и оправдать жестокие нравы героизируемого прошлого, но и вместе с тем несколько отгородиться от них.

У Толстого древне-эпическое проступает в героизации горской жизни, модернизированно, в духе Руссо, понятой в виде торжества самой «естественности». Хотя в описании Кавказа нарратором заметны разные, в том числе критические, акценты (зона Шамиля), но в зоне протагониста сохраняется пафос «абсолютного» прошлого, однако длящегося прошлого, ставшего настоящим и долженствующим перетечь в будущее.

Частые упоминания нарратором «Тараса Бульбы» предстоящего воспевания, оставления в памяти изображаемых героев заставляют поставить вопрос о том, что же для Гоголя важнее: само событие, факт реальности, в котором принимают участие запорожцы, или же отталкивающаяся от события и делающая его бессмертным «песнь» бандуриста / нарратора, самый акт наррации? «Ритуальная слава», акт наррации для Гоголя важнее любого факта действительности.

Говоря в «Тарасе Бульбе» о будущих восславителях своих персонажей, Гоголь имеет в виду прежде всего самого себя - не столько как эмпирическую личность, сколько как «автора» в качестве экзистенциально-эстетической данности /заданности. 
В «Учебной книге словесности для русского юношества», замысел которой возводят еще к 1830-м годам, Гоголь, определяя по-своему жанр эпопеи (единственным репрезентантом которой был для него Гомер), далее выделяет «меньшие [или «малые», по его же дальнейшим словам - С. Ш.] роды эпопеи», «составляющие как бы середину между романом и эпопеей», героем которых «бывает хотя частное и невидное лицо, но, однако же, значительное во многих отношениях для наблюдателя души человеческой» (Гоголь 6: 331). Исследователи уже относили (весьма справедливо) это жанровое определение к «Мертвым душам», но оно верно и применительно к «Тарасу Бульбе».

Гоголь писал в процитированном фрагменте, что в меньшем роде эпопеи героем бывает «частное и невидное лицо», но применительно к персонажам его «Тараса Бульбы» это справедливо лишь отчасти: они частные лица только в том плане, что не зависят напрямую ни от какой власти, что они сами себе власть. «Невидными» же их называть не приходится. Подобные и последующие замечания верны также во многом и относительно Хаджи-Мурата.

Принципиальны дальнейшие рассуждения Гоголя о меньшем роде эпопеи: «Ариост изобразил почти сказочную страсть к приключениям и к чудесному, которым была занята на время вся эпоха, а Сервантес посмеялся над охотой к приключениям, оставшимся, после рококо, в некоторых людях, в то время, когда уже самый век вокруг их переменился» (Гоголь 6: 332). Не совсем понятно, что имеется в виду под рококо, расцветшим в XVIII веке, ${ }^{7}$ очевидно, то, что сближает его с другими «вторичными художественными стилями» (Д. С. Лихачев) - готикой и барокко (об этом см. Шульц 1994).

Гоголь апеллирует к «Неистовому Роланду» и «Дон Кихоту», «несмотря на их шутливый тон» («несмотря» здесь маркирует не уступительность, а является данью современности, словно бы не замечающей «комического поэта» Гоголя), указывая также, что в них «всемирности нет, но есть и бывает полный эпический объем замечательных частных явлений» (Гоголь 6: 332).

«Всемирности нет» - это для Гоголя только сравнительно с Гомером, недостижимым образцом. На самом деле Ариосто и Сервантес, а вслед за ними Гоголь и Толстой так или иначе претендуют на всемирность, хотя и понимая трудность подобного замаха - ведь, как сказал поэт, «умчался век эпических поэм».

Гоголевские оценки продиктованы прежде всего его историзмом, осознанием им идеи развития и идеи уникальности каждого явления (именно два этих последних качества Мейнеке выделяет в качестве основы историзма). Вместе с тем акцент на «полный эпический объем замечательных частных явлений» [выделено - С. Ш.] сделать необходимо.

Гоголь реализует «всемирность», во-первых, через указание во второй редакции повести на будущего московско-петербургского царя, призванного осуществить «мессианскую» роль России. Во-вторых, «всемирность» «Тараса

${ }^{7}$ О связи Гоголя с рококо XVIII века см. ИвАницкий 2000. Впрочем, Стендаль относит к рококо творчество Бернини (XVII век) (см. СтЕНДАЛЬ 1978: 20). 
Бульбы» открывается в постоянных соотнесениях антропологическо-исторического, с одной стороны, и одуховотворенного, выходящего непосредственно из Бога природно-степного плана, с другой.

Одухотворенные картины природно-степного, завершающиеся в финале взлетом «гордой» птицы гоголь, крайне поэтизируют изображаемое и изображение: «Солнце выглянуло давно на расчищенном небе и живительным, теплотворным светом своим облило степь. Все, что смутно и сонно было на душе у казаков, вмиг слетело; сердца их встрепенулись, как птицы» (Гоголь 2: 317).

Сердца казаков уподобляются птицам, а сами же непосредственные птицы и все природно-живое составляют с казаками единый поэтический мир: метафора и ее основа переходят друг в друга. Под «поэтическим» мы в данном случае имеем в виду то, что близко «героическому» состоянию мира (Гегель), исконной архаике, категории возвышенного.

Дальнейшее описание степи напоминает в том числе видение Хомы Брута во время его полета с ведьмой (и тем самым оно вводит демонизм мотива панночки и в «Тарасе Бульбе», связывая героинь «Тараса Бульбы» и «Вия» воедино): «Степь, чем далее, тем становилась прекраснее. Тогда весь юг, все то пространство, которое составляет нынешнюю Новороссию, до самого Черного моря, было зеленою, девственною пустынею. Никогда плуг не проходил по неизмеримым волнам диких растений; одни только кони, скрывавшиеся в них, как в лесу, вытаптывали их. Ничего в природе не могло быть лучше: вся поверхность земли представлялась зелено-золотым океаном, по которому брызнули миллионы разных цветов. Сквозь тонкие, высокие стебли травы сквозили голубые, синие и лиловые волошки; желтый дрок выскакивал вверх своею пирамидальною верхушкою; белая кашка зонтикообразными шапками пестрела на поверхности; занесенный, Бог знает откуда, колос пшеницы наливался в гуще. Под тонкими их корнями шныряли куропатки, вытянув свои шеи. Воздух был наполнен тысячью разных птичьих свистов» (Гоголь 2: 317; вновь отметим устойчивую птичью символику).

В приведенной цитате мир степной природы является овнешнением и продолжением духа. Так это в основном понято в христианстве.

В-третьих, моментом «всемирности» выступает в «Тарасе Бульбе» акт наррации поэта-духовидца, «поющего» ритуальную славу, только и сохраняющуюся, когда история проходит и превращается в эсхатологию.

«Пение» переходит непосредственно в наррацию, в рассказ, в соответствии с трансформацией фольклорного проявления героического эпоса - былин - в богатырскую сказку. «Рыцари» «Тараса Бульбы» напоминают о богатырях; ср. замечание о потенциальных богатырях в первом томе «Мертвых душ». Сцена карнавального сражения Тараса с сыновьями, предвещая совсем не карнавальное убийство Тарасом Андрия, находит соответствие в эпизоде сражения Ильи Муромца с сыном (неузнанным вначале Ильей) в одной из былин. В итоге сражения Илья убивает сына, как позднее Тарас (Былины 1958: 195-202). 
Повесть Гоголя содержит элементы и былины, и богатырской сказки.

Подобно персонажам «Неистового Роланда» и «Дон Кихота», героев «Тараса Бульбы» обуревает страсть к приключениям: их служение не отменяет момента собственно приключенчества, к которому все гоголевские казаки, включая и Андрия, с его «частным» интересом, стремятся. Здесь, помимо связи с Ариосто и Сервантесом, можно указать также на перекличку со сходными мотивами поступков героев романтических исторических романов В. Скотта.

Что касается «Дон Кихота», то параллель к нему уже проводилась исследователями на материале «Мертвых душ». ${ }^{8}$ Однако роль сервантесовского романа более существенна для «Тараса Бульбы». Гоголь в «Учебной книге словесности» отметил, - напомним, - что Сервантес «посмеялся над охотой к приключениям, оставшимся... в некоторых людях, в то время, когда уже самый век вокруг их переменился» (Гоголь 6: 332).

В этой оценке - влияние постромантического историзма (не Просвещения, вопреки мнению В. Е. Багно), замечающего любые «анахронизмы».

«Дон Кихот» пародирует рыцарские романы, но амбивалентно, показывая также объективное величие императива следования высоким идеалам в неподходящих для этого обстоятельствах. В этом - и пафос Гоголя, предвосхищенный в процитированном в начале настоящей статьи высказывании Гете о необходимости «благоговения» «перед высокими невыполнимыми требованиями».

«Тарас Бульба» сам содержит черты рыцарского романа: тяга к приключениям, к борьбе за надличностные идеалы, культ прекрасной дамы у Андрия. Нарратор «Тараса Бульбы» постоянно называет своих героев рыцарями, и это многозначительная, сущностная обмолвка. Хотя нельзя исключать, что маркер «рыцарь» отсылает у Гоголя также к романтическим историческим романам В. Скотта.

В рыцарском романе «Парцифаль» Вольфрама фон Эшенбаха герой Гамурет, сообщив своей матери о выборе пути рыцаря, о своем желании «отличиться на чужбине», слышит от нее:

О плод родительского древа!

Ты добрым вскормлен молоком!

Прекрасной Дамой ты влеком!..

(ЭШенБАХ 1974: 267)

В данном контексте происходит характерное для средневековья определенное отождествление потенциальной Прекрасной Дамы с Богоматерью.

Еще более принципиальны последующие слова из «Парцифаля»: «В Любовь сильней, чем в Бога, верь!..» (ЭШЕНБАх 1974: 435).

\footnotetext{
${ }^{8}$ Первым это сделал М. де Вогюэ, см. также МАнH 1987, БАГно 1988, БАГно 2009, HoLL 1996.
} 
Так и в жизни Андрия панночка - некая Прекрасная Дама. Однако она оказывается из стана врага. В случае Андрия косвенные аллюзии образа панночки на фигуру Богоматери также возможны, хотя они звучат несколько смутно, вязко. Панночка ухаживает за Андрием, как мать. Она в определенной мере заменяет реальную мать Андрия, оставленную им в Малороссии. И как для Бульбы реальная мать его сыновей - нечто второстепенное, то, что не заслуживает внимания казака, так и панночка для него и других запорожцев - явление из этого же ряда. Для Андрия панночка - напоминание о ласковой и любящей матери, причем обе эти фигуры косвенно сливаются в данном случае с Богородицей.

Тезис рыцарского романа Вольфрама фон Эшенбаха «В любовь сильней, чем в Бога верь» становится своеобразным девизом Андрия, предающего свою веру ради Прекрасной Дамы. Правда, он вместе с панночкой приобретает - в тенденции повести, - можно сказать, другого Бога, католического. Но это только «вознаграждение» за соединение с панночкой, кстати, ни разу не названной по имени, что делает ее образ довольно обобщенным или даже анонимным - это символ «роковой» «соблазнительницы» вообще, но и, парадоксально, символ аллегорическо-символической Прекрасной Дамы.

В том числе через отсылку к своему предшествию - рыцарскому романукарнавализованный «в себе» «Дон Кихот» карнавализуется Гоголем через рецепцию-переинтерпретацию своей сюжетной и отчасти в целом жанровой модели в «Тарасе Бульбе».

Разве не донкихотовское начало толкает Тараса на все его поступки: на отмщение, на борьбу за прошлое [sic!] и будущее страны, за реально невозможное освобождение Остапа из польского плена?

В кодексе рыцарской чести Тараса, как и почти всех запорожцев отсутствует поклонение Прекрасной Даме; здесь можно увидеть развитие частной развенчивающей линии именно «Дон Кихота», где Дульсинея - фантом протагониста. Однако влюбленность Андрия в панночку и его уход от запорожцев есть реанимация мотива именно рыцарского романа, где рыцари могут из-за дамы сердца менять сюзерена. У Гоголя подобное окрашено в тона предательства, хотя одновременно подано в духе куртуазной любви рыцаря к даме. Такая амбивалентность - симптом рецепции также и традиции, следующей уже за собственно рыцарским романом, т. е. ренессансного «Дон Кихота». ${ }^{9}$ В «Дон Кихоте» также проблематизируется «самопонятность» исторического: своею условностью, очень напоминающая условную манеру комедий и трагедий Шекспира. И Сервантес, и Шекспир независимо друг от друга поверяют настоящее прошлым, все их богатые метаисторические смыслы идеалистически трактуют «большое время» истории.

Здесь же отметим некоторые, вероятно, более слабо выраженные субъективно, но так или иначе проступающие в аспекте исторической поэтики,

\footnotetext{
${ }^{9}$ Хотя нередко в романе Сервантеса отмечают также элементы барокко, не чуждые и Гоголю.
} 
мотивы рыцарского романа и одновременно пародии на него в лице «Дон Кихота» у Толстого. Хаджи-Мурат - почти что средневековый рыцарь, со своим кодексом личной чести и благородством, его «нукеры» предстают своего рода оруженосцами. «Средневековый» в данном случае имеет не только переносный смысл: Кавказ XIX века сохранял феодальный уклад жизни.

Западня, в которую попадает протагонист Толстого - раздвоение между двумя сюзеренами - сродни отдельным ситуациям, описываемым в рыцарском эпосе, этом субстрате «Дон Кихота». В связи с этим весьма правомерны замечания Д. Хермана о «благочестивом» («праведном», «богобоязненном») «молчании» Хаджи-Мурата, а также о том, что герой проходит в повести через своеобразную «инициацию» (HERMAN 2005: 1-3).

«Донкихотовский» идеализм Хаджи-Мурата проявляется в его желании остаться несломленным не взирая ни на какие обстоятельства. Но вопреки Сервантесу, Толстой это желание нисколько не высмеивает, показывая его единственно возможным.

Рыцарский эпос, как мы уже говорили, тесно связан со средневековым героическим эпосом, часто их рассматривают как явления одного порядка. Элемент рецепции жанра героического средневекового эпоса по линии исторической поэтики вскрывает своеобразное «эстетическое» («ренессансное», в данном случае понятое несколько сниженно) «оправдание» предательства Андрия у Гоголя, изменяющего правилам классического героического эпоса, всегда негативно изображавшего предателя - но не неприятеля, который обрисовывался с признанием его объективных достоинств. В линии «Андрий и панночка» можно увидеть также моменты ренессансной любовной новеллы, однако, развенчиваемые, т. к. любовная связь приводит к гибели Андрия.

Еще далее Гоголя идет в указанном аспекте исторической поэтики Толстой - он полностью оправдывает «двойного» «предателя» Хаджи-Мурата. Это оправдание понятно именно в контексте жанровой модели героического эпоса средневекового типа, ее нарушения. С обыденной, плоской точки зрения Хаджи-Мурат предал своих - но он «предал» затем и «чужих».

Подробно описывая отдельные проявления сознания Хаджи-Мурата, нарратор Толстого пытается показать, что его протагонист рассматривал несколько вариантов выхода из сложившейся сложной ситуации - в том числе возвращение после бегства на сторону Николая I, чтобы помочь ему завоевать Кавказ. Другим вариантом поведения Хаджи-Мурат имел совершенно автономное самостоятельное существование, но тоже в борьбе с Шамилем, которого он ненавидит не столько как «тирана», сколько из какой-то потаенной нравственной брезгливости.

Нарратор пытается показать, что в истории Хаджи-Мурата имеет место невыносимое стечение («сцепление») обстоятельств, при котором каждая мелочь влияет на нечто более важное - конфигурацию мировых сил и место человека в ней. Хаджи-Мурата не интересует верность или неверность (впрочем, уже это - нарушение канонов древнего и средневекового героического эпоса) определенной власти, его задача - спасти свою семью и сохранить себя 
как личность - хотя бы ценой смерти. Так сохраняют и утверждают себя умирающие Ромео и Джульетта у Шекспира, сюжет данной трагедии которого имеет архаические ритуальные истоки (ФРАнк-КАМЕНЕЦКий 1994-1996).

Ю. В. Манн на основе сходства коллизии враждующих родов сблизил «Тараса Бульбу» и «Ромео и Джульетту» (МАнн 2002), но в данном случае точнее говорить о параллелях повести Гоголя не к этой трагедии Шекспира, а к средневековому по преимуществу эпосу, послужившему отправной точкой и для самого Шекспира в целом. Кроме того, Андрий не утверждает себя в смерти. Андрий действует скорее по воле фатального стечения обстоятельств. Панночка же не погибает, а выживает единственно благодаря Андрию: все акценты по сравнению с Шекспиром смещены.

С другой стороны, трагическому измерению «Хаджи-Мурата» созвучны коллизии другой шекспировской трагедии - «Кориолан»: обвинения в мнимом [sic!] предательстве сопровождают человека предельно честного, достойного, выбирающего путь одинокого мужественного самостояния. ${ }^{10}$

Если Гоголь ставит акт наррации об истории на первый план по сравнению с самой историей, то в «Хаджи-Мурате» по-другому: акт наррации, сама наррация будут стремиться стать словно незаметными, нарочито безыскусными перед реальностью.

Вместе с тем характерно уже начало повести: «Я возвращался домой полями» (Толстой 1950: 5): повествование сразу же начинается с «я», т. е. с принципа субъекта, индивида, хотя далее этот принцип пытается снять себя в продолжении: «полями», с последующим описанием полевых цветов, напоминающим описание степи в «Тарасе Бульбе». Фольклорные горские произведения, о которых часто вспоминается в повести, также выдвигают на первый план не сам акт наррации, но ее значение.

Сходно описание акта наррации в исландских сагах (ответвляющихся от средневекового героического эпоса). В саге о «Гуннлауге змеином языке» протагонист говорит: «Сидите здесь и не помогайте ни той, ни другой стороне. Вы можете потом рассказать о нашей битве» (Исландские саги 1973: 530): т. е. будущему рассказчику предлагают не вмешиваться в исход битвы, чтобы он обладал привилегией беспристрастности, «вненаходимости»; это близко позиции нарратора «Хаджи-Мурата».

В саге «Об исландце-сказителе» конунг говорит о прослушанной саге: «Она мне очень понравилась. Она ничуть не хуже, чем то, о чем в ней рассказывается» (Исландские саги 1973: 535). Здесь сопоставляется акт наррации и содержание наррации, точнее, основа, ставшая содержанием наррации. Эту основу событий Толстой также не упускает из виду. Но все же факт действительности, связанный с реальной историей реального Хаджи-Мурата,

\footnotetext{
${ }^{10}$ Мы не разделяем распространенного мнения о некоей «гордыне» или «высокомерии» шекспировского Кориолана: все его действия - лишь реакция на непонимание окружающих и сложную сюжетную ситуацию в целом; герой изнутри него самого полностью оправдан и полностью понят Шекспиром.
} 
отступит у Толстого в тень перед переписанным заново мифом. После А. Ф. Лосева мы знаем, что миф - совсем не вымысел, а особого рода действительность (ЛОСЕВ 1993).

Считается, что «Хаджи-Мурат» стремится показать тираническую природу всякой власти - и петербургско-имперской в лице Николая I, и горской в лице Шамиля. Здесь можно согласиться только с идеей утверждения нарратором необходимости «анархического» сопротивления им обеим со стороны частного человека. Индивид в его частной правде (и здесь возникает - хотя и очень неполная - перекличка образа Хаджи-Мурата с образом Андрия) противопоставляется Толстым всем видам исторического как всеобщего.

Есть в этой повести Толстого нечто, заставляющее воспринять определенную «случайность» критики им персонализированной, субстантивированной власти: например, Хаджи-Мурат имеет в качестве варианта поведения возможное служение царю, он с удовольствием вспоминает беседу со старым Воронцовым. Среди представителей русских войск у Хаджи-Мурата появляются и сочувственники, и друзья - Марья Дмитриевна, Иван Матвеевич, Бутлер (хотя последний потом оправдывает отрезание головы Хаджи-Мурата условиями войны, что вызывает негативную реакцию Марьи Дмитриевны и нарратора). В этой связи припоминается сцена из рыцарского романа Кретьена де Труа «Ивэйн, или Рыцарь со львом», во время которой оба рыцаря великодушно готовы признать свое поражение.

Толстой в «Хаджи-Мурате» утверждает случайность персонификации власти, он бьет непосредственно против власти как таковой - «абстракции».

Натурфилософия «Хаджи-Мурата», сливающая воедино человека и репей, индивида и весь космо-гео-природный мир, грозит перевести тематизацию истории в род тематизации природно-естественного, чьим частным моментом - подлежащим у Толстого снятию - эта история и выступает. ${ }^{11}$ Толстой при этом очень тонко обыгрывает, в частности, второе название репья «татарин», косвенно намекая на мусульманство героя. Марья Дмитриевна, впрочем, так и говорит о протагонисте: «Он татарин, а хороший» (Толстой 1950: 96). Позднее сам рассказчик называет одного из горцев «татарином». Такое словоупотребление было вообще характерно для России XIX века.

Этот скрытый, но устойчивый условный «татарский» контекст повести вызывает ассоциации в том числе с темой былого противостояния монголотатар и русских, вплоть до эпохи Ивана Грозного; ср. образ истязаемого татарина в произведении «После бала», а также прямую татарскую топику в «Тарасе Бульбе», соединяющуюся там с топикой польской (прислужница прекрасной панночки, пленившей Андрия, - татарка). Автор/нарратор «Хаджи-Мурата», в отличие от автора /нарратора «Тараса Бульбы», хотел бы примирить русских и «татар».

${ }^{11}$ Ср.: «...история [в «Хаджи-Мурате» - С. Ш.] предстает царством механического и бессмысленного повторения..., а не природа и естественный уклад людей» (ШАТиРишвили 2003: 68). 
В «Войне и мире» история проявлялась в виде войны как негативно сверхъестественного. В «Хаджи-Мурате» история в истоке сюжета (образ поля) и в его финале отождествляется с торжеством естественности, в которой и преодолевается - природой. Сам Хаджи-Мурат - «естественный человек», «дикарь» в духе Руссо и «Простодушного» Вольтера (где протагонист доставлен из «первобытности» в «цивилизованный» мир).

Все это очень явственно, и напоминает оно о гоголевском переходе природного плана в историософский/эсхатологический. Но точки отталкивания у двух авторов разные. У Гоголя - история / эсхатология, у Толстого - «природа» (в этой связи пишут о «язычестве» Толстого: см. Гулин 1994: 112). Толстой далек от канонического христианства, для которого природа - овнешнение духа.

Преемственность между «Тарасом Бульбой» и «Хаджи-Муратом»- преемственность в том числе жанровых трансформаций, переходов и превращений-возвратов, динамики жанрового развития.

Изображение динамического сознания протагониста и отчасти сознаний всех показанных в горизонте его восприятия героев заставляет говорить об элементах предмодернизма у Толстого, что на материале «Анны Карениной» отметил еще В. В. Набоков (см. НАБоков 1996). Совершенно нельзя поэтому разделить мнение О. В. Сливицкой о том, что «характер Хаджи-Мурата создан внешним путем» (СливицКАя 2009: 434): ${ }^{12}$ Толстым раскрыто все внутреннее в этом характере, начиная от его семейного и интериоризированного социально-культурного становления до тайных глубин предсмертного мышления.

Хаджи-Мурат резко выделяется на фоне других героев своей исключительностью, значительным человеческим масштабом. В этом он является «романтическим» героем неромантического произведения. В «Тарасе Бульбе» же все герои-запорожцы, не только Тарас и его сыновья, значительны и масштабны, каждый - высок.

Смерть Тарасова рода не означает у Гоголя прекращения цепи истории, а начинает новый виток цепи. У Толстого же смерть Хаджи-Мурата - его подлинное торжество как индивида и одновременно это почти солипсический конец истории. Солипсический - для Хаджи-Мурата и нарратора /автора. Только нарратор/автор в толстовской повести и равен Хаджи-Мурату своим масштабом, своими оценками внешнего (мирского) и внутреннего (сознания). Но и мирское, и сознание - все это моменты бытия.

Как писал М. Хайдеггер, «существование во всякий миг может устанавливаться так, чтобы выбирать между собою и миром, он может принять любое решение - изнутри того, что попадается ему навстречу в мире, или же

${ }^{12}$ Хотя исследовательница, вместе с тем, говорит и о «психологизации» событий Толстым, но тут же вновь добавляет: «Исключительность личности Хаджи-Мурата не в наполнении его внутренней жизни, а в ее энергетическом заряде» (СливицКАЯ 2009: 436). Нет, и в «наполнении внутренней жизни»! Тем более это не противоречит идее «энергетического заряда». 
изнутри себя самого» (ХАЙдеггеР 1995: 170). Хаджи-Мурат в итоге выбирает себя, а не мир, как бы он ни вслушивался в бытие мира накануне предощущаемой гибели.

Мир - это ведь и семья протагониста, за которую он тревожится. И тревожась за мир, Хаджи-Мурат вынужден отказаться от мира ради мира же, а в конечном счете - ради себя. В его смерти есть элемент высокого самоубийства, допускавшегося античными стоиками (еще один контекст становления идеи героя - античный, вливающийся в данном случае в христианский).

Блаженный Августин, чьи идеи отчасти перекликаются со стоическими, также допускал случаи определенного оправдания самоубийства - когда это нужно для сохранения чести. В качестве примера в своем богословско-историософском трактате «О Граде Божием» Августин приводит ситуации Лукреции и Катона. Катон умертвил себя в Утике, поскольку для него «было бесчестьем жить под властью победившего Цезаря». Как и толстовский ХаджиМурат, Катон боялся за жизнь сына, «пощады которого он желал и ждал от Цезаря» (Августин 2000: 40-41).

Однако Августин отмечает некую «нелогичность», по его мнению, поступка Катона, который не умертвил с собою своего сына, оставляя последнего якобы на благосклонность Цезаря. Но на фоне ситуации Катона история Хаджи-Мурата также говорит о том, что Хаджи-Мурат, погибая почти добровольно, так же хотел бы сохранить в живых своего сына, свою семью в целом. Но он знал, что последнего, скорее всего, не произойдет.

Уже в начале «Хаджи-Мурата» говорится о некоем (пока неназванном) человеке, победившем даже в смерти. Так и «Смерть Ивана Ильича», охватывающая описание всей жизни протагониста, начинается с констатации его смерти. Читатель «Хаджи-Мурата» тщательно подготавливается нарратором к будущей смерти протагониста: «Он [Хаджи-Мурат - С. Ш.] знал, что думает теперь в последний раз, и необходимо решение» (Толстой 1950: 102).

Бахтин отмечал, что «мыслящий человек» характерен для «эмотивного и семейно-бытового романа» (БАХтин 2012: 337), разрушаемого Гоголем и Толстым, однако оставляющими самого «мыслящего человека».

Хронотоп такого человека в названной форме романа («эмотивная и семейно-бытовая») - «чужой мир» (в толстовской повести - мир русских войск), «дорога по родному миру», дом. Все три названных реализации хронотопа даны у Толстого. Однако дом - это то, что теряет Хаджи-Мурат, а дорога оказывается дорогой из родного мира в смерть. Так формы эмотивного и семейно-биографического романа, намеченные Толстым в двух своих первых романах, в «Хаджи-Мурате» в самом деле разрушаются (как вообще в его поздних повестях и в «Воскресенье»). Толстой приходит к предпочтению бесприютности, бегства, смерти - хотя и вынужденных для Хаджи-Мурата, но свободно и сознательно им принимаемых.

Гоголь еще более далек от названных форм романа. В «Тарасе Бульбе» ценности дома, уюта, семьи - отрицательные. Это то, от чего Тарас и все запорожцы бегут. Их надличностный идеал предполагает верность родному, 
но, в бахтинских терминах, не как «моему» (что характерно именно для семейно-биографического романа), а как «нашему».

Перед побегом Хаджи-Мурата охватывает «росистая свежесть лунной ночи», «свисты и щелканье сразу нескольких соловьев из сада, примыкавшего к дому» (Толстой 1950: 103). Потом этот «соловьиный» мотив будет развит нарратором в последующих эпизодах гибели протагониста и предшествующих им (ср. Шкловский 1981: 276).

Перед побегом, т. е. перед заведомой гибелью - так она телеологически передана у Толстого - Хаджи-Мурат припоминает фольклорно-природные образы: «И он вспомнил сказку тавлинскую о соколе, который был пойман, жил у людей и потом вернулся в свои горы к своим. Он вернулся, но в путах, и на путах остались бубенцы. И соколы не приняли его» (Толстой 1950: 102).

Здесь возникает перекрещивание с карнавальной топикой шутовских бубенцов, объективно сближающихся с теми бубенцами, о которых вспоминает Хаджи-Мурат, причем здесь топика несет не только сниженное, но и высокое значение. Хаджи-Мурат - в какой-то степени «шут» при Николае I. В связи с этим и в связи с общей скрытой «татарской» топикой повести вспоминается ряжение Иваном Грозным князя Симеона Бекбулатовича в шутовского русского царя и «поклонение» ему со стороны «умалившего» себя Грозного, ${ }^{13}$ что, по сути, являлось актом, символически венчающим закат монголо-татарской власти на Руси (ср. также указанное косвенное помещение нарратором фигуры Хаджи-Мурата в христианский контекст через деталь отрубленной головы). Вместе с тем глубокая мусульманская религиозность Хаджи-Мурата для нарратора /автора вполне самоценна.

В связи с символической и философской шутовской топикой возникает другая аллюзия и интертекстуальная перекличка: в романе Вольфрама фон Эшенбаха мать, отправляя будущего Парцифаля в мир, из хитрости обряжает его в подчеркнуто шутовское одеяние:

«Сын просит дать ему коня?
Что ж, он получит от меня
Коня-то бишь, слепую клячу -
И шутовской наряд в придачу,
А в одеянье дурака
Узнает он наверняка
Толпы насмешки и побои:
Мол, коли шут - не лезь в герои!..
И ненаглядный мальчик мой
Сам в страхе кинется домой...»
Так поступить она решила
И в тот же вечер сыну сшила
Из мешковины балахон,
Подобье неких панталон

${ }^{13}$ См. об этом деянии Грозного (ЛиХАчЕВ-ПАНчЕНКО-ПоНЫРКо 1984: 26). 
И туфли из телячьей кожи, Что и на туфли не похожи, Да с погремушками колпак, Что скажешь? - вылитый дурак!..

(ЭШЕНБАХ 1974: 321)

Шутовство становится некоей скрытой основой характера будущего Парцифаля, оно приобретает не только амбивалентный, но и прямо высокий характер самоумаления, отсутствия притязаний на власть и величие, оно оправдывает в глазах нарратора /автора те поступки протагониста, которые могут показаться наивными, ребячливыми с точки зрения «здравого смысла».

Это шутовство Парцифаля свидетельствует о глубокой связи рыцарского эпоса с карнавальным началом, делает подвиги протагониста неофициозными, неформальными. Когда Бахтин глубоко и остроумно писал об элементах шутовства в «лирическом герое» Блока, поклоняющегося своей Прекрасной Даме, он имел в виду раздвоение рыцарского в этом герое, раздвоение, заложенное уже в самом рыцарском романе и в пародиях на него в виде романов Сервантеса и Ариосто.

Шутовские бубенцы протагониста предвещают и шутовские бубенцы из новеллы Э. По «Бочонок амонтильядо», в которых, анализируя финал новеллы, Бахтин увидел карнавальный символ победы героя По над смертью.

«Слепая кляча» и «шутовской наряд», о которых говорит мать будущего Парцифаля, прямо предвосхищают образ сервантесовского Дон Кихота. Как видим, герой Сервантеса, а с героем также элементы поэтологии сервантесовского произведения предсказаны уже непосредственно в самом рыцарском романе, они не косвенно, а прямо (т. е. не только пародийно) переходят оттуда к Сервантесу. В связи с этим также вспомним, что в рыцарском романе Кретьена де Труа «Ивэйн, или Рыцарь со львом» в одном из эпизодов Ивэйн назван «безумным рыцарем»:

Ивэйн раздетый, безоружный,
И не иначе как недужный,
Свалившись, погрузился в сон.

(КРЕТЬЕН ДЕ ТрУА 1974: 94-95)

Аттестация «безумный» напоминает о будущем Дон Кихоте, о «неистовом» Роланде Ариосто, описывающем безумие героя, влюбившегося в Анджелику. Амбивалентно рассуждая о собственном помешательстве в одном из эпизодов сервантесовского романа, Дон Кихот вспоминает безумие Амадиса Гальского в качестве архетипа. Заметим, что безумие Амадиса произошло не от чтения рыцарских романов, а внутри самого рыцарского романа, что приподнимает и «безумие» Дон Кихота.

Но не такова ли и оценка Андрия нарратором «Тараса Бульбы»- как своего рода «безумца», из-за его порыва любви и одновременно предательства? Сам Гоголь эти два порыва четко различает, показывая не простую измену, а 
определенную раздвоенность героя и самой ситуации, в которую он попадает. И эту раздвоенность Андрия необходимо воспринимать во всей ее сложности, не вешая на героя однозначного ярлыка «предатель».

«Шутовство», «безумие» проступает и в толстовском Хаджи-Мурате но это высокое шутовство, высокое безумие.

В данном контексте элементы рецепции героического эпоса усложняются: объективная историческая память жанра толстовского произведения воскрешает все, самые разные страницы былого противостояния народов, эксплицируя доминирование то одной, то второй из враждующих сторон. В итоге же, по объективной идее повести, не оказывается правых и виноватых: «нет в мире виноватых» - говорит название одной из незавершенных поздних толстовских повестей.

«Сокол» Хаджи-Мурат понимает свою обреченность и все равно действует вопреки всему. Это близко фаталистическим мотивам исландских саг, например, «Саге о Гисли» или «Саге о Ньяле». Гисли, объявленный «вне закона» и попадающий в ситуацию, когда каждый может безнаказанно его убить, продолжает сопротивляться, ощущая энергию, вкус жизни, понимая и принимая при этом также свою обреченность, знаки которой он видит в своих вещих снах:

Видел я сон: владыка
Льдины луны ладьи
Мне окровавил плечи,
О гна огня океана.
Скальд осужден расстаться
С жизнью и с милой женою,
Но смерть положит предел
Годам невзгод и печалей.

(Исландские саги 1973: 75)

Подобно Гисли ощущает свою фаталистическую обреченность и ХаджиМурат. Примечательно, что Гисли называет себя «скальдом», т. е. сказителем, «певцом» - и такое же «поэтическое» восприятие мира имеет ХаджиМурат. Значение категории «поэтического» напоминает здесь о гегелевском «героическом» состоянии мира, о стремлении нарратора сблизиться с поэзией как формой восприятия жизни. «Поэты» - также и все запорожцы.

То же осознанное приятие - и даже фаталистическое воспевание - своей обреченности составляет один из ведущих мотивов лирики поэта XX века Пауля Целана. В творчестве Целана, в развитие его собственных претекстов, отсутствует мотив сопротивления мрачным обстоятельствам; гибельность принимается сполна, вплоть даже до некоторого восхваления палача (см., например, «Фугу смерти»). В целановском стихотворении «Черные хлопья», где припоминается мрачная картина из украинской истории, описывается ситуация, близкая коллизиям «Тараса Бульбы» (линия Янкеля) и «ХаджиМурата» (западня, в которую попадает герой): 
Представь себе, что и здесь [на Украине - С. Ш.] наступает зима, ныне в тысячный раз, в краю, где течет широчайший поток:

Иакова небесная кровь, благословленная топорами...

О лед неземной красноты - гетман их с казаками

Бродит в меркнущих солнцах...

(ЦЕЛАН 2008: 11)

И далее поэт почти «по-толстовски» вводит вроде бы мелкие, частные («необязательные», в терминологии Л. Я. Гинзбург) детали, создающие духовно-психологическую ауру ситуации:

Дитя, ах платок,

Чтоб закутаться мне, когда шлемы блистают,

Когда эта глыба розовая трещит, когда снежною пылью

рассыпается скелет

твоего отца, растоптана копытами песнь о кедрах...

(ЦЕЛАН 2008: 11)

Хотя, безусловно, детали Целана - символические, они не вполне самоценны, в отличие от метода Толстого, создающего через них прежде всего «эффект реальности».

Отношение к жертвам истории у Целана ближе толстовскому, чем гоголевскому: это сострадание. Однако Целан в целом не осуждает, а даже както полуиронически-трагически «восславляет» гонителей. Картины природы в «Черных хлопьях» одухотворены и вписаны в человеческую жизнь, т. е. интериоризированы; они в основном несамостоятельны - в противоположность Гоголю и Толстому.

Перед смертью Хаджи-Мурат слышит уже бывшею знакомой ему ранее песню, исполняемую Ханефи: «В песне говорилось о том, как джигит Гамзат угнал с своими молодцами с русской стороны табун белых коней. Как потом его настиг за Тереком русский князь и как он окружил его своим, как лес, большим войском. Потом пелось о том, как Гамзат порезал лошадей и с молодцами своими засел за кровавым завалом убитых коней и бился с русскими до тех пор, пока были пули в ружьях и кинжалы на поясах и кровь в жилах. Но прежде чем умереть, Гамзат увидал птиц на небе и закричал им: „Вы, перелетные птицы, летите в наши дома и скажите вы нашим сестрам, матерям белым девушкам, что умерли мы все за хазават“» (Толстой 1950: 104).

Вновь мы видим сходную с гоголевской птичью символику (ср. описание соловьев; здесь еще возникают ассоциации с лермонтовскими мотивами изгнанника - «туч», «дубового листка» и т. п.), а также перекликающуюся с гоголевской апологией «разбойничьей» Сечи (особенно в первой редакции «Тараса Бульбы») толстовскую апологию горских нарушителей общепринятых правил.

Песня Ханефи напоминает Хаджи-Мурату другую, сложенную его матерью: «Булатный кинжал твой прорвал мою белую грудь, а я приложила 
к ней мое солнышко, моего мальчика, омыла его своей горячей кровью, и рана зажила без трав кореньев, не боялась я смерти, не будет бояться и мальчик-джигит» (Толстой 1950: 105).

Вообще воспоминания постоянно охватывают Хаджи-Мурата - в нарастающем предчувствии гибели, охватывают уже и во время боя с русскими войсками: «И все эти воспоминания пробегали в его воображении, не вызывая в нем никакого чувства: ни жалости, ни злобы, ни какого-либо желания». И далее следует принципиальная фраза - и в плане поэтики, изображения «потока сознания», интроспекции, и в плане художественной философии Толстого: «Все это казалось так ничтожно в сравнении с тем, что начиналось и уже началось для него» (Толстой 1950: 117).

«Начиналось и уже началось»- смерть, только и придающая, согласно Толстому, смысл человеческой личности, ее существованию в вечности. В преддверии смерти сознание Хаджи-Мурата напоминает сознание Ивана Ильича, но у первого готовность к гибели отчетливее. Бездонная многозначительность фразы «начиналось и уже началось» проясняется только в целостном контексте толстовского творчества. Вся история Хаджи-Мурата, из которой по-драматургически выхвачены ключевые события, предстает в виде осознания протагонистом готовности к смерти (начиная с указания на песню, придуманную его матерью).

Особо заметим, что речь идет не просто о смерти, но об осознании смерти, в том числе о готовности к ней; важным обертоном этой темы выступает мотив сопротивления (отсутствующий у Целана) всему мирскому, внешнему, «ложному», имитационному. Что бы ни говорил Толстой об энергии жизни своего героя, объективно он показал энергию его готовности к смерти. Так предвосхищается хайдеггеровское «бытие-к-смерти».

Отрезанная голова Хаджи-Мурата в финале напоминает многие иные смещенные, жуткие, «натуралистические» формы восприятия телесности у позднего Толстого, начиная с предкризисной «Анны Карениной», где прекрасное, цветущее женское тело нарратор бросает под колеса чудовищного механизма.

Детализированно описанная мертвая голова Хаджи-Мурата предстает не столько как синекдоха (часть вместо целого), сколько как метафора (отождествление части, ставшей целым, с чем-то сугубо земным, человеческибиологическим и одновременно потусторонним): «Это была голова, бритая, с большими выступами черепа над глазами и черной стриженой бородкой и подстриженными усами, с одним открытым, другим полузакрытым глазом, с разрубленным и недорубленным бритым черепом, с окровавленным запекшейся черной кровью носом. Шея была замотана окровавленным полотен цем. Несмотря на все раны головы, в складе посиневших губ было детское доброе выражение» (Толстой 1950: 109).

Именно упоминание «детского доброго выражения» выступает надбиологическим, «потусторонним» элементом описания варварской забавы мнимо цивилизованных людей с головой погибшего. Одновременно - как уже 
говорилось - отрубленная голова Хаджи-Мурата проецируется на евангельское событие усекновения головы Иоанна Крестителя. ${ }^{14}$

\section{Литература}

Августин 2000 = Августин Блаженный: $O$ граде Божием. Минск-Москва, 2000.

БАГНО 1988 = БАГНо В. Е. Дорогами «Дон Кихота». Судьба романа Сервантеса. Москва, 1988.

БАГНО 2009 = БАГНО В. Е. «Дон Кихот» 6 России и русское донкихотство. Санкт-Петербург, 2009.

БАХТИН 1996 = БАХТИН М. М. «Слово о полку Игореве» в истории эпопеи. В кН.: БАХтин М. М. Собрание сочинений в 7 томах. Т. 5. Москва, 1996. 39-41.

БАХТИН 2012 = БАХТИН М. М. К эмотивному и семейно-биографическому роману. В кн.: БАХтин М. М. Собрание сочинений в 7 томах. Т. 3. Москва, 2012. 337-339.

Бойко 1983 = Бойко М. Н. Комментарии. В кн.: Толстой Л. Н. Собрание сочинений в 22 томах. Т. 14. Москва, 1983. 476-508.

БРосовА 2006 = БросовА Н. 3. «Лесные тропы» бытия. Феноменология истории Мартина Хайдеггера. Вопросы философии 2006/11: 155-163.

Былины 1958 = Былины в 2 томах. Т. 1. Москва, 1958.

ВинОГРАДОВ 1997 = ВиногРАДОВ И. А. «Тарас Бульба» и отношение Н. В. Гоголя к католицизму (к изучению вопроса). В кн.: Гоголезнавчі студіï. Вип. 2. Ніжин, 1997. 31-47.

ГЕГЕЛЬ 2001 = ГЕГЕЛЬ Г. В. Ф. Лекцุии по эстетике. Т. 1. Санкт-Петербург, 2001.

ГоГоль $=$ Гоголь Н. В. Полное собрание сочинений и писем в 17 томах. Москва-Киев, 2009-2010.

ГРИФФИтС-РАБинович $2005=$ ГРИФФитс Ф. Т., РАБинович С. Дж. Третий Рим. Классический эпос и русский роман (от Гоголя до Пастернака). Санкт-Петербург, 2005.

Гулин 1994 = Гулин А. В. «Не перестаю думать о Хаджи-Мурате». Родина 1994/3-4: 111-115.

Гуминский 1985 = Гуминский В. М. «Тарас Бульба» в «Миргороде» и «Арабесках». В кн.: Гоголь: история и современность. Москва, 1985. 240-258.

ДиЛьтЕй 2001 = ДИЛЬТЕЙ В. Фрагменты «Поэтики». В кн.: ДИЛЬТЕЙ В. Собрание сочинений в 6 томах. Т. 4. Москва, 2001. 423-435.

ДушечкинА 1983 = ДушечкинА Е. В. «Тарас Бульба» в свете традиций древнерусской воинской повести. В кн.: Гоголь и современность. Творческое наследие писателя в движении эпох. Киев, 1983. 30-35.

ИвАнИцКИЙ 2000 = ИвАНИцКИй А. И. Гоголь. Морфология земли и власти. Москва, 2000.

Исландские саги 1973 = Исландские саги. Ирландский эпос. Москва, 1973.

КАЗАКОВ 2012 = КАЗАКОВ А. А. Ценностная архитектоника произведений Ф. М. Достоевского. Дисс. докт. филол. наук. Томск, 2012.

${ }^{14}$ О. В. Сливицкая справедливо обратила внимание на параллелизм описания гибели Хаджи-Мурата и гибели солдата Авдеева, «в которую перешла его простая, самоотверженная жизнь» (СливицКАЯ 2009: 432). 
КРЕТЬЕН ДЕ ТрУА 1974 = КРЕТЬЕН ДЕ ТРУА: ИвэйН, иЛи РЫцарь со ЛЬВОМ. В кн.: Средневековый роман и повесть. Москва, 1974. http://litena.ru/books/item/f00/s00/z000 0045/st002.shtml.

КРивонос 2006 = КРивонос В. Ш. Повести Гоголя: пространство смысла. Самара, 2006.

ЛИХАЧЕВ-ПАНЧЕНКО-ПОНЫРКО 1984 = ЛИХАЧЕВ Д. С., ПАНЧЕНКО А. М., ПОНЫРКО Н. В. Смех в Древней Руси. Ленинград, 1984.

Лосев $1993=$ Лосев А. Ф. Диалектика мифа. В кн.: Лосев А. Ф. Миф-число-сущчность. Москва, 1993. 5-216.

МАнн 1987 = МАнн Ю. В. В поисках живой души. «Мертвые души»: писатель -критика-читатель. Москва, 1987.

МАнн 2002 = МАнн Ю. В. Мотив и жанр (к своеобразию повести Гоголя «Тарас Бульба»). В кн.: Русская повесть как форма времени. Томск, 2002. 135-143.

МЕЙНЕКЕ 2004 = МЕЙНЕКЕ Ф. Возникновение историзма. Москва, 2004.

МЕЛЕТинский 1994 = МЕЛЕТинский Е. М. Заметки о средневековых жанрах, преимущественно повествовательных. В кн.: Проблема жанра в литературе средневековья. Москва, 1994. 7-26.

МЕЛЕТИНСКИЙ 2001 = МЕЛЕТИНСКИй Е. М. От мифа к литературе. Москва, 2001.

Михайлов А. Д. 1976 = МихАЙЛов А. Д. Франиузский рыцарский роман и вопросы типологии жара в средневековой литературе. Москва, 1976.

Михайлов А. Д. 1995 = МихАЙЛОВ А. Д. Франиузский герочческий эпос. Bonросы nоэтики и стилистики. Москва, 1995.

МихАйлов А. В. $2006=$ МихАйЛОВ А. В. Дильтей и его школа. В кн.: МихАйлов А. В. Историческая поэтика и герменевтика. Санкт-Петербург, 2006. 225-320.

НАБОков 1996 = НАБОков В. В. Лекиии по русской литературе. Москва, 1996.

ПрийМА 1954 = ПрийМА Ф. Я. «Слово о полку Игореве» в творчестве Гоголя. В кн.: Гоголь. Статьи и материаль. Ленинград, 1954. 137-156.

Пумпянский $2000=$ Пумпянский Л. В. Гоголь. В кн.: Пумпянский Л. В. Классическая традиция. Москва, 2000. 257-342.

РАДИЩЕВ 1938 = РАДИЩЕВ А. Н. Полное собрание сочинений в 3 томах. Т. 1. МоскваЛенинград, 1938.

СЛИВИЦКАЯ $2009=$ СливИЦКАЯ О. В. «Истина в движеньи». О человеке в мире Л. Толстого. Санкт-Петербург, 2009.

Слово 2010 = Слово о полку Игореве. Санкт-Петербург, 2010.

СолОвьЕВ $1999=$ СоловьЕВ В. С. Владимир Святой и христианское государство. В кн.: Соловьев В. С. Россия и вселенская Церковь. Минск, 1999. 207-232.

СТЕНДАЛЬ 1978 = СТЕНДАЛЬ: Собрание Сочинений в 12 томах. Т. 10. Прогулки по Риму. Москва, 1978.

Сухих 1987 = Сухих И. Н. Проблемы поэтики Чехова. Ленинград, 1987.

ТАМАРЧЕНКО 2001 = ТАМАРЧЕНКО Н. Д. АвТор, герой и повествование (к соотношению «эпопейного» и «романного» у Гоголя). В кн.: Поэтика русской литературы. К 70-летию проф. Ю. В. Манна. Москва, 2001. 22-28.

Толстой 1950 = Толстой Л. Н. Полное собрание сочинений в 90 томах. Т. 35. Москва, 1950.

ФЕДОРОВ 1985 = ФЕДОРОВ В. В. Поэтический мир Гоголя. В кн.: Гоголь: история $u$ современность. Москва, 1985. 132-163.

ФРАНК-КАМЕНЕЦКИЙ 1994-1996 = ФРАНК-КАМЕНЕЦКИЙ И. Г. К генеЗИсу легендЫ о Ромео и Юлии. Русский текст 1994/2: 158-177, 1995/3: 167-205, 1996/4: 178-203. 
ХАЙДЕГГЕР 1995 = ХАЙДЕГГЕР М. Исследовательская работа В. Дильтея и борьба за историческое мировоззрение в наши дни. В кн.: 2 текста о В. Дильтее. Москва, 1995. 137-201.

ЦЕЛАН 2008 = ЦЕЛАН П. Стихотворения. Проза. Письма. Москва, 2008.

ШАТиРишвили 2003 = ШАТиРишвили 3. По ту сторону возвышенного: кавказский топос в «Хаджи-Мурате» Л. Н. Толстого. В кн.: Л. Н. Толстой в 1850-е годы: рождение художника. Тула, 2003. 62-68.

Шкловский 1959 = Шкловский В. Б. Последняя повесть Л. Толстого. Bonpocb литературы 1959/7: 121-147.

Шкловский 1981 = Шкловский В. Б. Энергия заблуждения. Книга о сюжете. Москва, 1981.

Шульц 1994 = Шульц С. А. Гоголь. Личность и художественный мир. Москва, 1994.

Шульц 2007 = Шульц С. А. Топика памятника в творчестве Гоголя и пушкинская традиция. Русская литература 2007/1: 130-141.

ЭЙХЕНБАУМ 1931 = ЭЙХЕНБАУМ Б. М. Л. Толстой. Кн. 2. 60-е годы. Москва, 1931.

ЭшенБАх 1974 = ЭшенБАх Вольфрам фон: Парцифаль. В кн.: Средневековый роман и повесть. Москва, 1974. http://litena.ru/books/item/f00/s00/z0000045/st005.shtml.

Herman 2005 = Herman D. Khadzhi-Murat's Silence. Slavic Review 64 (2005): 1-23.

Holl $1996=$ Holl B. T. Gogol's Captain Kopeikin and Cervantes' Captive Captain. A Case of Metaparody. The Russian Review 55 (1996): 681-691.

Proffer 1967 = Proffer C. R. The Simile and Gogol's Dead Souls. The Hague, 1967. 